\title{
HUMAN MESENCHYMAL STEM CELL RESPONSES TO HYDROSTATIC PRESSURE AND SHEAR STRESS
}

\author{
P. Becquart ${ }^{1,}$, M. Cruel ${ }^{2, \dagger}$, T. Hoc ${ }^{2}$, L. Sudre ${ }^{1}$, K. Pernelle ${ }^{2}$, R. Bizios ${ }^{3}$, D. Logeart-Avramoglou ${ }^{1}$, H. Petite ${ }^{1}$ \\ and M. Bensidhoum ${ }^{1, *}$
}

${ }^{1}$ Laboratory of Bioengineering and Bioimaging for Bone Articulation, University of Paris, Paris, France
${ }^{2}$ Laboratoire de Tribologie et Dynamique des Systèmes. Ecole Centrale de Lyon, Ecully Cedex, France
${ }^{3}$ Department of Biomedical Engineering, The University of Texas at San Antonio, San Antonio, TX, USA

†These authors contributed equally to this research project.

\begin{abstract}
The effects of mechanical stimuli to which cells are exposed in vivo are, at best, incompletely understood; in this respect, gene-level information regarding cell functions which are pertinent to new tissue formation is of special interest and importance in applications such as tissue engineering and tissue regeneration. Motivated by this need, the present study investigated the early responses of human mesenchymal stem cells (hMSCs) to intermittent shear stress (ISS) and to cyclic hydrostatic pressure (CHP) simulating some aspects of the biological milieu in which these cells exist in vivo. Production of nitric oxide (NO) and mRNA expression of several known mechanosensitive genes as well as ERK1/2 activation in the hMSC response to the two mechanical stimuli tested were monitored and compared. NO production depended on the type of the mechanical stimulus to which the hMSCs were exposed and was significantly higher after exposure to ISS than to CHP. At the conditions of NO peak release (i.e., at $0.7 \mathrm{~Pa}$ for ISS and 50,000 Pa for CHP), ISS was more effective than CHP in up-regulating mechanosensitive genes. ERK1/2 was activated by ISS but not by CHP. The present study is the first to report that PGTS2, IER3, EGR1, IGF1, IGFBP1, ITGB1, VEGFA and FGF2 are involved in the response of hMSCs to ISS. These findings establish that, of the two mechanical stimuli tested, ISS is more effective than CHP in triggering expression of genes from hMSCs which are bioactive and pertinent to several cell functions (such as cell differentiation and release of specific growth factors and cytokines) and also to tissue-related processes such as wound healing.
\end{abstract}

Keywords: Human mesenchymal stem cells, shear stress, hydrostatic pressure, NO, mechanosensitive genes, ERK1/2.

*Address for correspondence:

Morad Bensidhoum

Laboratory of Bioengineering and Bioimaging for Bone Articulation (B2OA, UMR CNRS 7052)

University of Paris 7

PRES Paris Cité

10 Avenue de Verdun

75010 Paris, France

Telephone Number: 33157278539

FAX Number: 33157278571

E-mail: morad.bensidhoum@univ-paris-diderot.fr

\section{Introduction}

Tissue engineering has sought to simulate the biochemical and biophysical milieu to which tissues (and their constituent cells) are exposed in vivo by judicious choices of chemical and mechanical stimuli applied to cultured cells (including stem cells) in vitro. This is the rationale that bone-related cells, for example, have been cultured under dynamic conditions in various bioreactors systems (Gardel et al., 2014; Yeatts et al., 2013). Since in such cases, however, cells are exposed simultaneously to a combination of mechanical stimuli (specifically, shear stress and/or tensile stresses as well as hydrostatic pressure), it is not possible to isolate and, thus, identify the specific mechanical stimulus that triggers cellular responses pertinent to new tissue formation.

Elucidation of this important aspect (specifically, identification of the mechanical stimulus responsible for cell responses and functions of physiological processes pertinent to clinical applications) could have major implications in the production, for example, of bone constructs of clinically-relevant sizes. In this respect, harvesting a small sample of bone marrow, isolating autologous, human, mesenchymal stem cells (hMSCs), expanding them in vitro, and inducing differentiation into the osteogenic phenotype (Friedenstein et al., 1966; Friedenstein et al., 1968) has great, but yet not fully realised, potential for tissue engineering applications. It should be noted that the effect of shear stress (at 1.2 Pa for $90 \mathrm{~min}$ ) on the proliferation and differentiation of hMSCs cultured on tissue-culture polystyrene was reported in the literature (Grellier et al., 2009; Scaglione et al., 2008). Very few studies (for example, Huang and Ogawa, 2012; Miyanishi et al., 2006) have addressed the impact of hydrostatic pressure alone on hMSCs at the cellular and molecular levels. To date, there are no literature reports comparing the effects of these two mechanical stimuli on hMSC differentiation.

The objective of the present study was, therefore, to investigate and compare the early responses of human MSCs (cultured onto flat, tissue-culture polystyrene plates) when these cells were exposed to either shear stress or hydrostatic pressure. To this aim, first NO production, a hallmark of cell response to mechanical loading (Tjabringa et al., 2006), was assessed as a function of either applied intermittent shear stress (ISS) or cyclic hydrostatic pressure (CHP). Subsequently, the effects of ISS and CHP on the expression of select, early, mechanosensitive, hypoxia-related, osteogenic genes as well as on ERK1/2 


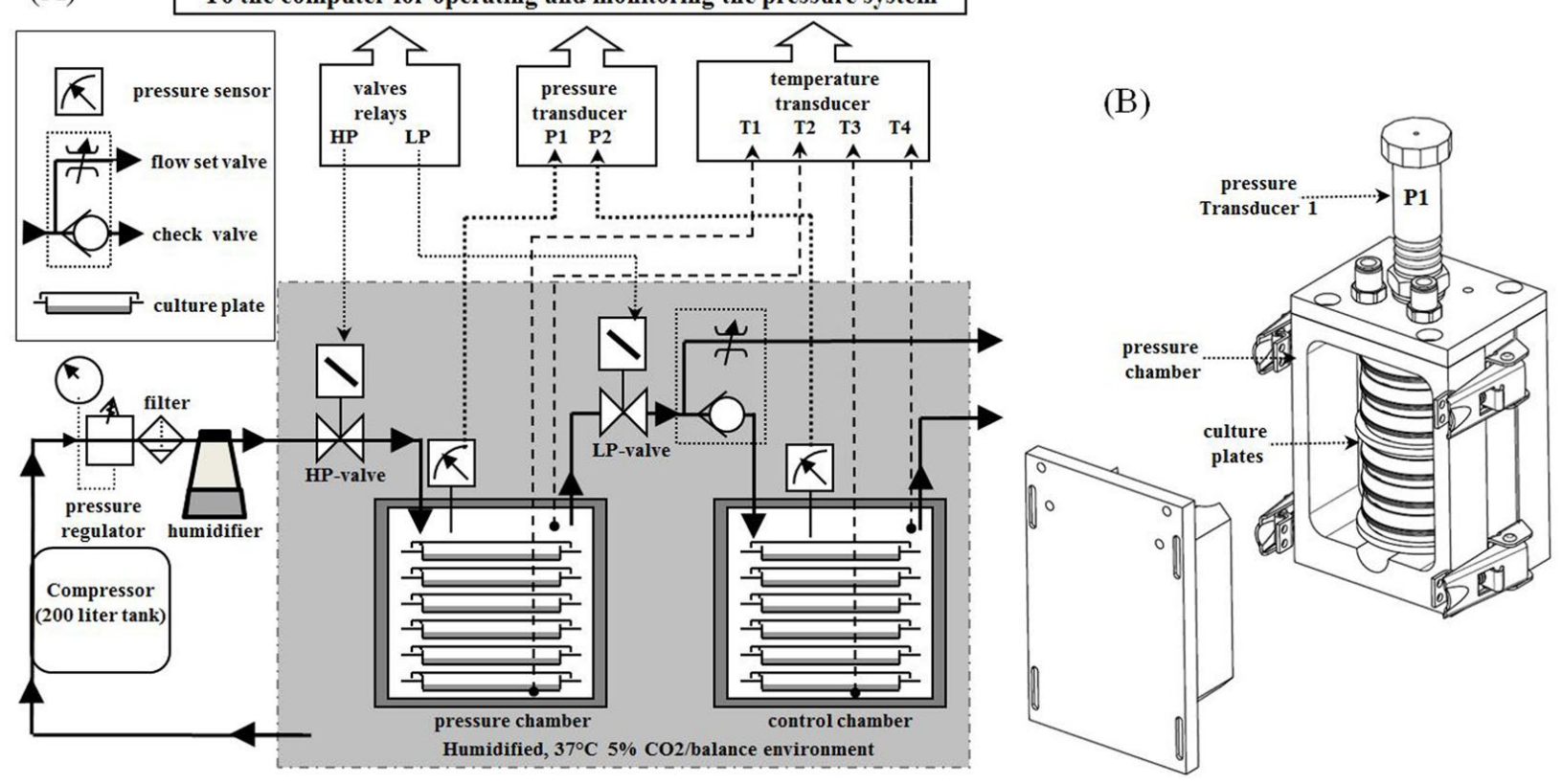

Fig. 1. Schematic (not to scale) illustration of the laboratory system used to exposed cells to cyclic hydrostatic pressure (CHP). This pressure system was used to expose cells to mechanical stimulation by increasing the pressure of the gaseous phase above the supernatant media under which the cells were cultured. Briefly, a Labview program controlled and maintained cyclic and sinusoidal pressure in the range of 0 to 100,000 $\mathrm{Pa}$ above atmospheric pressure and a maximum frequency of $2 \mathrm{~Hz}$ in a sealed, stainless steel, pressure chamber. This chamber was designed to accommodate a stack of six, round (each $6 \mathrm{~cm}$ in diameter) cell-culture, tissue-culture polystyrene dishes. The chosen pressure level of the gas phase inside the pressure chamber was maintained under continuous monitoring using a pressure regulator and by opening and closing as, and when, needed the inlet (high pressure, HP) and outlet (low pressure, LP) solenoid valve relays that controlled the flow of a humidified air mixture into and out of the pressure chamber. A control chamber, similar to the pressure chamber but maintained at atmospheric pressure, was used to maintain the control specimens during the experiments with cells. Both chambers were kept, and operated, in a humidified, $37{ }^{\circ} \mathrm{C}, 5 \% \mathrm{CO}_{2}$ /balance air environment. The pressures (P1, P2) and temperatures $(\mathrm{T} 1, \mathrm{~T} 2, \mathrm{~T} 3, \mathrm{~T} 4)$ inside the two chambers were monitored in real time using respective pressure and temperature transducers. (A) View of the laboratory pressure system used to expose cells to CHP. (B) Magnified view of the pressure chamber.

activation (a pathway which participates in cellular mechanotransduction) were assessed and compared to the level of the mechanical stress which had induced maximal NO release from hMSCs.

\section{Materials and Methods}

\section{Cyclic pressure system}

A custom-made, cyclic, computer-operated, pressure system (Fig. 1), inspired by published models (Nagatomi et al., 2001), was designed, built and calibrated. The pressure system used in the present study exposed cells to mechanical stimulation by increasing the pressure of the gaseous phase above the supernatant media under which the cells were cultured (Fig. 1). Briefly, a Labview program (National Instruments, Nanterre, France) controlled and maintained cyclic, sinusoidal pressure in the range of 0 to $100,000 \mathrm{~Pa}$ and a frequency in the range of 0 to $2 \mathrm{~Hz}$, in a sealed, stainless steel, pressure chamber. This chamber was designed to contain six, round, tissue-culture polystyrene dishes (each $6 \mathrm{~cm}$ in diameter). The desired pressure level was achieved by using a pressure regulator and continuously monitoring the pressure of the gas phase inside the pressure chamber by opening and closing (as, and when, needed) the inlet (high pressure) and outlet (low pressure) solenoid valve relays that controlled the flow of a humidified air mixture (containing $78 \% \mathrm{~N}_{2}, 20.9 \% \mathrm{O}_{2}$, $0.9 \% \mathrm{Ar}, 0.03 \% \mathrm{CO}_{2}, 0.17 \%$ other gases) into and out of the pressure chamber. A control chamber, similar to the pressure chamber but not exposed to pressure, was used to maintain the control specimens during experiments. For the purpose of the present study, both chambers were kept and operated in a humidified, $37^{\circ} \mathrm{C}, 5 \% \mathrm{CO}_{2} /$ balance air environment. The pressure (P1, P2) and temperature (T1, $\mathrm{T} 2, \mathrm{~T} 3, \mathrm{~T} 4)$ values in the chambers were monitored in real time using pressure and temperature transducers (Fig. 1).

\section{Shear stress system}

Exposure of the cell distal membranes to shear stress was achieved by flowing the cell-culture liquid medium through low-wall microchannels ( $\mu$-Slide) on whose surfaces $\left(2.5 \mathrm{~cm}^{2}\right)$ the cells were cultured; during these experiments, the medium flow was in the axial direction of the microchannels ( $\mu$-Slide). 
Shear Stress System (Ibidi system; Germany)

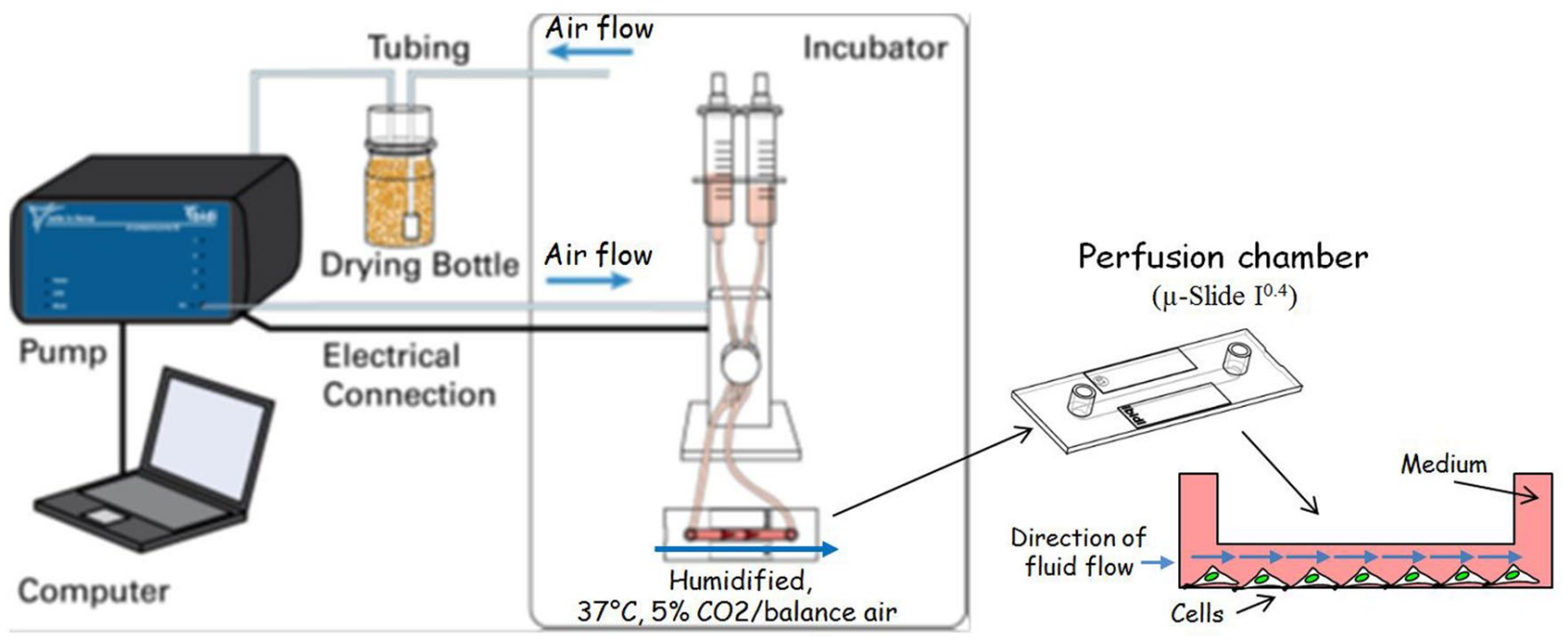

Fig. 2. Schematic (not to scale) illustration of the Ibidi system used to expose cells to intermittent shear stress (ISS). Except for the computer and electronic components, the rest of the Ibidi system was kept, and operated, in a humidified, $37^{\circ} \mathrm{C}, 5 \% \mathrm{CO}_{2}$ /balance air environment during experiments with cells. The Shear Stress (Ibidi) System contained a computer controlled air pump and a Fluidic Unit (i.e., two media-containing reservoirs connected to one cell-containing perfusion chamber). Cells seeded onto the bottom surface of the perfusion chamber were exposed to the prescribed shear stress.

The Ibidi Pump System (Ibidi-Integrated BioDiagnostics, Am Klopferspitz, Germany), used for this purpose, consisted of the following components: (i) the Ibidi Pump (which is a computer controlled air pump); (ii) the Fluidic Unit (consisting of two, cell-media reservoirs connected to an air pressure pump; (iii) a perfusion set; (iv) $\mu$-Slide; and (v) an electrically-controlled valve set (Fig. 2). This system allows either continuous or pulsatile, unidirectional flow of the cell-culture medium through the microchannels ( $\mu$-Slide) at a constant rate in the range of 0.03 to $35 \mathrm{~mL} / \mathrm{min}$, corresponding to a shear stress of 0.03 to $15 \mathrm{~Pa}$, respectively. For the purposes of the present study, the Fluidic Unit was kept and operated in a humidified, $37^{\circ} \mathrm{C}, 5 \% \mathrm{CO}_{2} /$ balance air environment.

\section{Calibration of the mechanical systems}

The temperature inside the compression chamber was monitored while this chamber was maintained under standard cell culture conditions. The maximum temperature increase recorded, under 100,000 $\mathrm{Pa}, 2 \mathrm{~Hz}$ for $3 \mathrm{~h}$ was $0.5{ }^{\circ} \mathrm{C}$. To validate the applied pressure, a pressure of $50,000 \mathrm{~Pa}$ was applied in the two compression chambers before each experiment and the values were measured using the two pressure transducers P1 and P2.

The Ibidi Pump Control software controlled the outgoing pressure applied to the Fluidic unit. Shear stress due to flow rate was only a result of the outgoing pressure, the defined perfusion set and the specific $\mu$-Slide (Note: these operating details were provided by Ibidi, the manufacturer of the instrument). Before each experiment, the flow rate was measured (according to the procedure recommended by Ibidi) to ensure that the shear stress applied to the cells corresponded to the chosen value.
These calibration results provided assurance regarding the performance of the two mechanical systems, which were then used in the experiments with cells.

\section{Human mesenchymal stem cells (hMSCs)}

Human MSCs were isolated from human bone marrow obtained as discarded tissue during routine bone surgery after patient informed consent and in accordance with the procedures approved by the Human Experimentation and Ethic Committees of the Lariboisiere Hospital (Paris, France). Two preparations of hMSCs at passage 2 were used in the present study: one contained MSCs from one donor; the other was a mixture of MSCs from six donors. MSCs from one donor were used in the NO-related experiments. When more donors became available, it was decided to combine their cells into one sample in order to minimise variability across these donors. This cell preparation, the sample of MSCs mixed from six donors, was used in all other experiments. Harvesting of hMSCs was accomplished as follows (Bensidhoum et al., 2004): The aspirated bone marrow was diluted in $\alpha$-Minimal Essential Medium ( $\alpha$ MEM) media. Nucleated cells were counted and suspended in $\alpha$-MEM containing $10 \%$ foetal calf serum (FCS). Primary nucleated cells were seeded at the density of $10^{5}$ cells $/ \mathrm{cm}^{2}$ of tissue-culture polystyrene surface area, and were cultured under standard cell culture conditions (i.e., $5 \% \mathrm{CO}_{2}$ /balance air, humidified, $37^{\circ} \mathrm{C}$ environment). After three days of culture, non-adherent cells were discarded during supernatant media change. The supernatant cell-culture medium was changed three times a week during cell expansion. When the cells were confluent (within about 12 days of culture), the hMSCs were detached using $0.25 \%$ trypsin-EDTA and were 
plated at the density of $3 \times 10^{3}$ cells $/ \mathrm{cm}^{2}$ in tissue culture polystyrene dishes for further cell culture.

\section{Exposure of hMSCs to either shear stress or hydrostatic pressure}

hMSCs suspended in $\alpha$ MEM (containing $10 \%$ FCS) were seeded at $44 \times 10^{3}$ cells $/ \mathrm{cm}^{2}$ onto either a perfusion polystyrene chamber $\left(\mu\right.$-Slide $\mathrm{I}^{0.4}$, measuring $50 \times 5 \mathrm{~mm}^{2}$; Am Klopferspitz, Germany) or on the bottom surface of cell culture polystyrene dishes (each $6 \mathrm{~cm}$ in diameter) and allowed to adhere (under standard cell culture conditions) for $2 \mathrm{~h}$; at that time, the supernatant media were replaced with fresh $\alpha \mathrm{MEM}$ (containing $2 \%$ FCS) and the cells were cultured overnight under standard cell culture conditions. The next day, the media in the perfusion chamber and the supernatant in the cell culture dishes were replaced by fresh aMEM (containing $2 \%$ FCS); the cells were kept under standard cell culture conditions for $30 \mathrm{~min}$ before exposure to the mechanical stimuli of interest to the present study.

Shear stress was applied by connecting the perfusion chamber to the Ibidi system. The cells were then exposed to shear stress of either $0.1,0.7,2.1$ or $4.2 \mathrm{~Pa}$ and a frequency of $2.8 \mathrm{~Hz}$ for $30 \mathrm{~min}$. Controls for these experiments were hMSCs maintained in parallel under similar cell culture conditions but not exposed to shear stress.

For the cyclic hydrostatic pressure experiments, three, cell-containing, tissue culture polystyrene dishes were placed inside the pressure chamber. The hMSCs were then exposed to cyclic hydrostatic pressure of either 10,000, $50,000,75,000$ or $100,000 \mathrm{~Pa}$ at $2 \mathrm{~Hz}$ for $30 \mathrm{~min}$. Controls for these experiments were hMSCs maintained in parallel under similar cell culture conditions but not exposed to cyclic hydrostatic pressure.

\section{Assays for determining select hMSC responses to mechanical stimuli \\ Measurement of nitric oxide}

Immediately following exposure of hMSCs to the mechanical stimuli tested, the supernatant media of each experimental and respective control samples were collected and stored at $-80{ }^{\circ} \mathrm{C}$ until determination of their $\mathrm{NO}$ content. For this purpose, the combined nitrite $\mathrm{NO}_{2}^{-}$and nitrate $\mathrm{NO}_{3}^{-}$(stable metabolites of $\mathrm{NO}$ ) was determined using the Griess reagent (containing $1 \%$ sulphanilamide, $0.1 \%$ naphthylethylenediamine dihydrochloride, and $2.5 \mathrm{M} \mathrm{H}_{3} \mathrm{PO}_{4}$ ) method, and a Nitrate/Nitrite colorimetric assay kit (Cayman Chemical Company, Ann Arbor, MI, USA) according to the manufacturer's instructions. Addition of the Griess reagent converted the nitrite contained in each sample of interest to the present study to a purple azo compound. Quantitation of the Nitrate/ Nitrite concentration was determined using in parallel serial $\mathrm{NaNO}_{2}$ dilutions (in the $5-35 \mu \mathrm{M}$ range) in $\alpha \mathrm{MEM}$ (containing $2 \% \mathrm{FCS}$ ) to obtain a nitrate standard curve; the detection limit of this assay was $1 \mu \mathrm{M}$. Light absorbance of each sample was measured at $540 \mathrm{~nm}$ using a microplate reader ( $\mu$ Quant, BIO-TEK Instrument Inc, Colmar, France).

\section{Real time polymerase chain reaction (RT-PCR)}

Cells, from the experimental and respective control samples, were collected at prescribed time points, specifically, immediately, as well as $1 \mathrm{~h}$ and $6 \mathrm{~h}$ after exposure of the cells to each mechanical stimulus tested. Expression of the mRNA of select genes was determined quantitatively using RT-PCR. For this purpose, total RNA was isolated from the hMSCs using the TRIzol ${ }^{\circledR}$ Reagent method and following the manufacturer's (Invitrogen, Illkirch, France) instructions. The RNA concentration and purity were determined using a NanoDrop spectrophotometer (NanoDrop 1000, Labtech, Palaiseau, France). Following isolation, $500 \mathrm{ng}$ total RNA was reverse-transcribed into cDNA using the Superscript II Transcriptase Kit (Invitrogen) and random hexamers (used as primers). Each RT-PCR analysis was performed in triplicate using 25 ng cDNA (RNA equivalent). Amplification of the cDNA using TaqMan ${ }^{\circledR}$ gene expression assays of genes encoding for PTGS2, PTGES, IER3, EGR1, RUNX2, ALP, HIF1A, VEGFA, ITGB1, FGF2, IGF1, IGFBP1 and 18S (all reagents were from Applied Biosystems Inc, Illkirch, France; Hs00167257_m1, Hs01573472_g1, Hs00610420_ m1, Hs00174674_m1, Hs00152928_m1, Hs00231692_m1, Hs01029144_m1, Hs00936371_m1, Hs00900054_m1, Hs00559595 m1, Hs00266645 m1, Hs01547656 m1, Hs00236877_m1 and Hs 99999901_s1, respectively) and TaqMan Universal PCR Master Mix (Applied Biosystems Inc) were performed using an iCycler thermocycling apparatus (MyiQTM Single-Color Real-Time PCR; BioRad Laboratories, Marnes la Coquette, France). For gene expression measurements, the endogenous control 18S RNA (house-keeping gene which has a constant expression level in hMSCs) was used as an internal control in relative RT-PCR. Relative gene expression (fold change) was calculated using the $2^{-\Delta \Delta C T}$ method and was stated as increase above baseline, that is, gene expression from hMSCs cultured under standard cell-culture conditions in the absence of either shear stress or hydrostatic pressure for similar time periods.

\section{Western blot analysis}

After exposure to either shear stress or hydrostatic pressure, the hMSCs were washed immediately with ice-cold phosphate-buffered saline (PBS) and scraped from their respective substrates. Proteins were extracted using cell lysis buffer (containing $62 \mathrm{mM}$ Tris- $\mathrm{HCl}$ (pH 6.8), $10 \%$ glycerol, $2 \%$ sodium dodecyl sulphate (SDS), and $2 \%$ $\beta$-mercaptoethanol) supplemented with phenyl methyl sulfonyl fluoride and phosphatase inhibitor cocktails I and II (all chemicals from Sigma-Aldrich, L'Isle d'Abeau Chesnes, France). Total protein concentration was determined using a bicinchoninic acid protein assay (BCA method; Bio-Rad). For Western blots, $10 \mu \mathrm{g}$ of total protein was loaded on $7.5 \%$ SDS-PAGE for electrophoresis and was electro-transferred to nitrocellulose membranes (BioRad). These membranes were subsequently blocked with Tris-buffered saline (containing $0.1 \%$ Tween-20 and $5 \%$ bovine serum albumin) at room temperature for $1 \mathrm{~h}$. After blocking, each membrane was probed at $37^{\circ} \mathrm{C}$ for $1 \mathrm{~h}$ with 

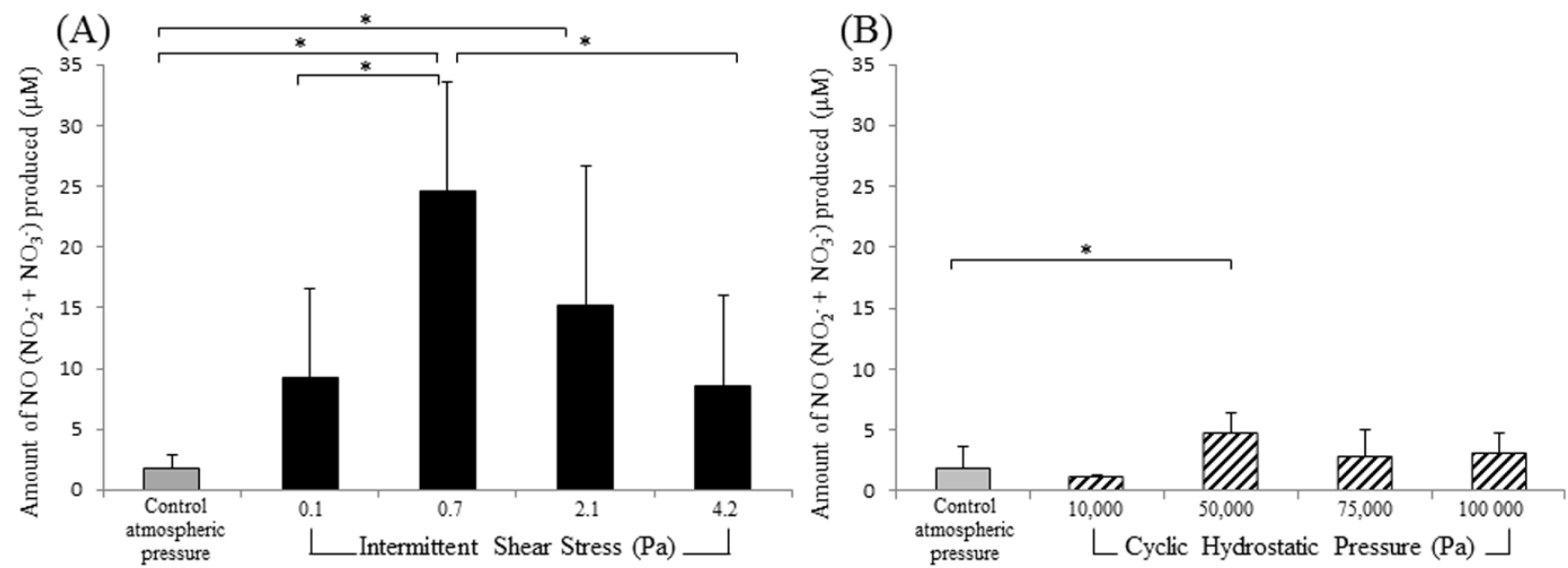

Fig. 3. Effects of either ISS or CHP on nitric oxide (NO) production by adult human mesenchymal stem cells (hMSCs). (A) The hMSCs were exposed to ISS in the range of 0.7 to $4.2 \mathrm{~Pa}$, at $2.8 \mathrm{~Hz}$ for $30 \mathrm{~min}$. (B) The hMSCs were exposed to $\mathrm{CHP}$ in the range of 10,000 to $100,000 \mathrm{~Pa}$, at $2 \mathrm{~Hz}$ for $30 \mathrm{~min}$. $* p<0.05$ (compared by one-way ANOVA with Bonferroni's post-hoc test).

the following primary antibodies (i) anti phosphorylated ERK1/2 (Thr202/Tyr204, \#4370S; Cell Signalling, Ozyme, Saint Quentin Yvelines, France); and (ii) anti beta-tubulin (T4026; Sigma-Aldrich), which were used following the manufacturer's protocols. In order to visualise the protein bands, anti-Rabbit secondary antibody (conjugated to horse radish peroxidase; Jackson ImmunoResearch, Newmarket, UK) and a chemo-luminescence detection system (LumiLight Western blotting substrate; Roche, Meylan, France) were used. The protein bands were semi-quantitatively evaluated using densitometry. Values of the phosphoERK1/2 levels were normalised to their respective betatubulin protein levels.

\section{Inhibition and activation of phosphorylated ERK1/2} In order to confirm the role of phosphorylated ERK $1 / 2$ in the hMSCs mechano-induced response, U0126 (SigmaAldrich) was used to inhibit ERK1/2 phosphorylation. For this purpose, the cells were pre-treated with $10 \mu \mathrm{M} /$ mL U0126 (under standard cell culture conditions) for $30 \mathrm{~min}$ prior to their exposure to either intermittent shear stress or cyclic hydrostatic pressure. Phorbol 12-Myristate 13-Acetate (PMA), a positive control of ERK activation, was used to induce ERK1/2 phosphorylation. For this purpose, hMSCs were exposed to a final concentration of $500 \mathrm{ng} / \mathrm{mL}$ PMA (under standard cell culture conditions) for $30 \mathrm{~min}$.

\section{Statistical analysis}

The NO production data from either ISS or CHP experiments were analysed by one-way ANOVA with Bonferroni's post-hoc test. Gene up-regulation data from ISS and CHP for each gene were analysed using $t$-test analysis to assess statistical significance. $t$-test was performed to compare only two groups and one-way ANOVA was performed to compare 3 groups or more. The confidence interval was set at $95 \%$, and the significance level at $p<0.05$. All experiments were run in triplicate at three separate times.

\section{Results}

\section{Effects of mechanical stimuli on NO release from hMSCs}

Intermittent shear stress

The mean value of $\mathrm{NO}$ (determined as combined $\mathrm{NO}_{2}^{-}$and $\mathrm{NO}_{3}^{-}$) production from $\mathrm{hMSCs}$ not exposed to intermittent shear stress (and maintained at atmospheric pressure) for $30 \mathrm{~min}$ (controls) was $1.74 \pm 1.19 \mu \mathrm{M}$ (Fig. 3A, grey bar). After exposure of hMSCs to shear stress of either 0.1, $0.7,2.1$ or $4.2 \mathrm{~Pa}$ above atmospheric pressure for $30 \mathrm{~min}$, the mean values of NO were $9.22 \pm 7.37,24.62 \pm 8.98$, $15.24 \pm 11.41$ and $8.61 \pm 7.39 \mu \mathrm{M}$, respectively (Fig. 3A, black bars). Fold-increase values of NO in the supernatant media from hMSCs exposed to shear stress of either 0.1, $0.7,2.1$ or $4.2 \mathrm{~Pa}$ above atmospheric pressure for $30 \mathrm{~min}$ were 5.28, 14.11, 8.73 and 4.93, respectively. Compared to results obtained from the respective controls (i.e., hMSCS not exposed to intermittent shear stress), the NO content in the supernatant media was significantly $(p<0.05)$ higher than when the hMSCs were exposed to shear stress at 0.7 and 2.1 Pa. Maximum NO release was obtained when the cells were exposed to an intermittent shear stress of $0.7 \mathrm{~Pa}$ for $30 \mathrm{~min}$ (Fig. 3A, black bar).

\section{Cyclic hydrostatic pressure}

The mean value of $\mathrm{NO}$ (determined as combined $\mathrm{NO}_{2}^{-}$ and $\mathrm{NO}_{3}^{-}$) production from hMSCs not exposed to cyclic hydrostatic pressure at atmospheric pressure for $30 \mathrm{~min}$ (controls) was $1.80 \pm 1.76 \mu \mathrm{M}$ (Fig. 3B, grey bar). After exposure of hMSCs to cyclic hydrostatic pressure at either $10,000,50,000,75,000$ or $100,000 \mathrm{~Pa}$ above atmospheric pressure for $30 \mathrm{~min}$, the mean NO values were $1.15 \pm 0.11$, $4.69 \pm 1.75,2.81 \pm 2.17$ and $3.62 \pm 1.73 \mu \mathrm{M}$, respectively (Fig. 3B, black-hatched bars). Compared to results obtained from the respective controls (i.e., hMSCs not exposed to cyclic hydrostatic pressure), fold-increase values of NO in the supernatant media of hMSCs exposed to CHP were $0.64,2.60,1.56$ and 1.69 , respectively. Compared to the respective controls (i.e., hMSCs not exposed to pressure), 

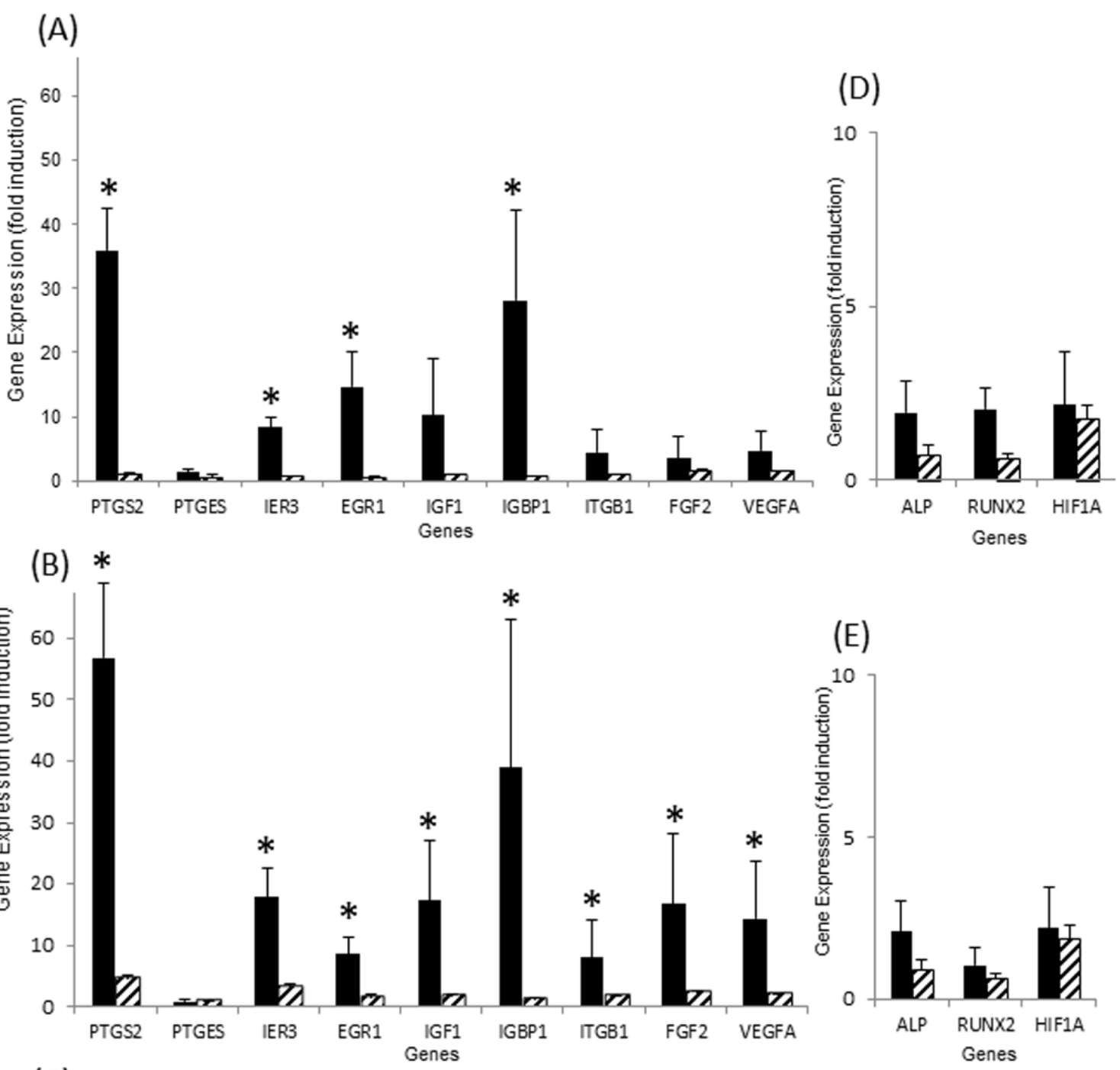

(C)

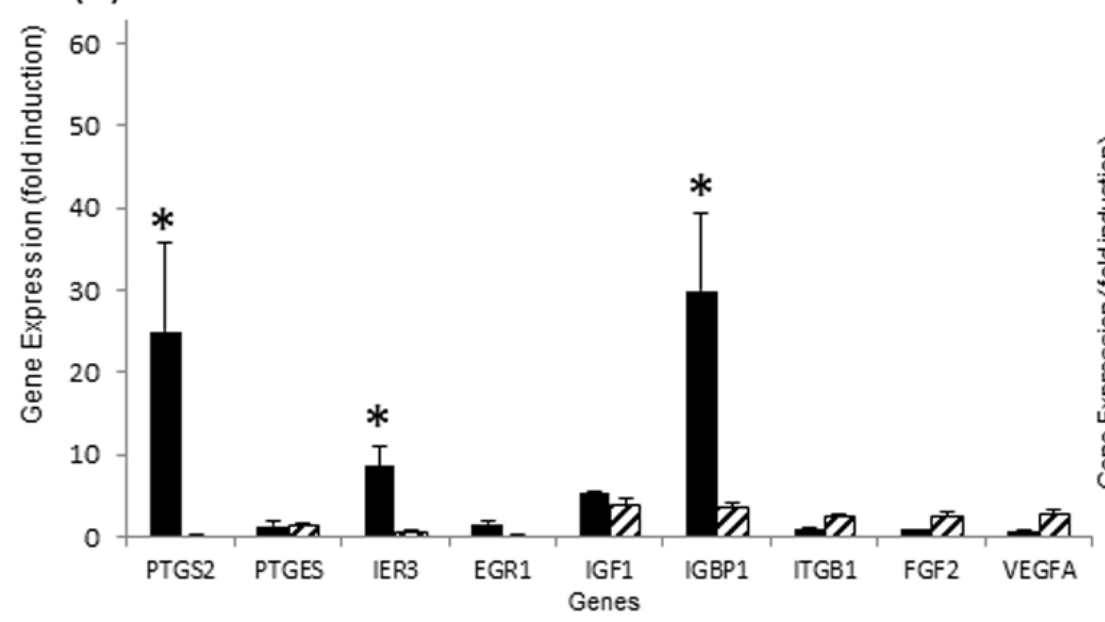

(F)

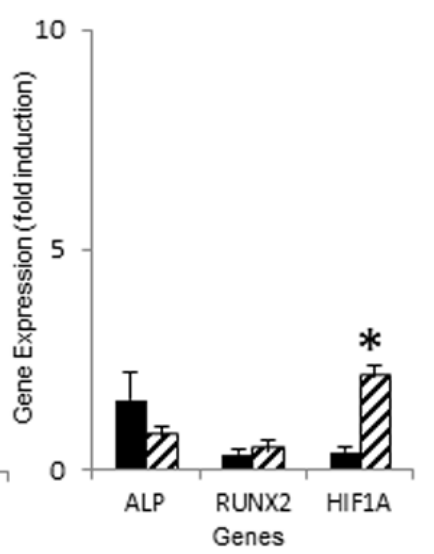

Fig. 4. Time course of select gene expression by hMSCs exposed to either ISS ( $0.7 \mathrm{~Pa}$ at $2.8 \mathrm{~Hz}$ for $30 \mathrm{~min})$ or CHP (50,000 $\mathrm{Pa}$ at $2 \mathrm{~Hz}$ for $30 \mathrm{~min})$. Expression of early mechano-sensitive genes after exposure of hMSCs to the tested mechanical stimuli for the following time periods: (A) $0 \mathrm{~h},(\mathbf{B})$ at $1 \mathrm{~h}$, and $(\mathbf{C})$ at $6 \mathrm{~h}$. Expression of the ALP, RUNX2 and HIF1A genes after exposure of hMSCs to the mechanical stimuli for the following time periods: (D) immediately $(0 \mathrm{~h}),(\mathbf{E})$ at $1 \mathrm{~h}$, and $(\mathbf{F})$ at $6 \mathrm{~h}$. Black bars $=\mathrm{hMSCs}$ exposed to ISS $(0.7 \mathrm{~Pa}$ at $2.8 \mathrm{~Hz})$ for $30 \mathrm{~min}$. Hatched bars $=\mathrm{hMSCs}$ exposed to $\mathrm{CHP}\left(50,000 \mathrm{~Pa}\right.$ at $2 \mathrm{~Hz}$ ) for $30 \mathrm{~min}$. ${ }^{*} p<0.05$ (gene up-regulation under ISS compared to results obtained under CHP, T-test). ALP = alkaline phosphatase; EGR1 = early growth response 1; FGF2 = fibroblast growth factor 2; HIF1A = hypoxia inducible factor 1, alpha subunit; IER3 = immediate early response 3; IGF1 = insulin-like growth factor 1; IGFBP1 = insulin-like growth factor binding protein 1; ITGB1 = integrin beta 1; PTGES = prostaglandin E synthase; PTGS2 = prostaglandin-endoperoxide synthase 2; RUNX2 = runt-related transcription factor 2; VEGFA $=$ vascular endothelial growth factor $\mathrm{A}$. 
Table 1. Genes monitored in the present study.

\begin{tabular}{|c|c|c|c|c|c|c|}
\hline \multicolumn{7}{|c|}{ Mechano-sensitive Genes } \\
\hline & & \multicolumn{4}{|c|}{$\begin{array}{c}\text { Results following exposure of adult human } \\
\text { mesenchymal stem cells to: }\end{array}$} & \multirow[t]{3}{*}{$\begin{array}{c}\text { Shear stress (SS) or hydrostatic pressure (HP) } \\
\text { other cells }\end{array}$} \\
\hline & & \multicolumn{2}{|c|}{ Shear stress } & \multicolumn{2}{|c|}{ Hydrostatic pressure } & \\
\hline Gene & $\begin{array}{l}\text { Protein: Full name } \\
\text { Protein: Function }\end{array}$ & $\begin{array}{c}\text { Bone } \\
\text { marrow } \\
\text { tissue }\end{array}$ & $\begin{array}{c}\text { Adipose } \\
\text { tissue }\end{array}$ & $\begin{array}{c}\text { Bone } \\
\text { marrow } \\
\text { tissue }\end{array}$ & $\begin{array}{c}\text { Adipose } \\
\text { tissue }\end{array}$ & \\
\hline PTGS2 & $\begin{array}{l}\text { Prostaglandin-endoperoxide } \\
\text { synthase } \\
\text { Converts arachidonic acid to } \\
\text { prostaglandin endoperoxide } \\
\mathrm{H}_{2} \\
\end{array}$ & $\begin{array}{l}\text { Hoey } \\
\text { et al. } \\
(2012)\end{array}$ & $U N$ & $U N$ & $U N$ & $\begin{array}{l}\text { (SS) Goat adipose MSC, Knippenberg et al. (2005) } \\
\text { (SS) Mice osteoblast, Lau et al. (2006) } \\
\text { (SS) Rat MSC, Kreke et al. (2008) } \\
\text { (SS) Human Dental Pulpe Cell, Kraft et al. (2010) } \\
\text { (SS) MG63, Lee et al. (2008) } \\
\text { (SS) MC3T3, Tanaka et al. (2005) }\end{array}$ \\
\hline PTGES & \begin{tabular}{|l} 
Glutathione-dependent \\
prostaglandin E synthase \\
Generates prostaglandin $\mathrm{E}$ \\
(PGE) from prostaglandin $\mathrm{H}_{2}$ \\
\end{tabular} & $U N$ & $U N$ & $U N$ & $U N$ & (SS) MC3T3, Thi et al. (2007) \\
\hline IER3 & $\begin{array}{l}\text { Radiation-inducible } \\
\text { immediate-early gene IEX-1 } \\
\text { Growth and stress associated } \\
\text { early response gene }\end{array}$ & $U N$ & $U N$ & $U N$ & $U N$ & $\begin{array}{l}\text { (stretching) human periodontal ligament cells, Wang } \\
\text { et al. (2011) }\end{array}$ \\
\hline EGR1 & $\begin{array}{l}\text { Early growth response } 1 \\
\text { DNA binding protein } \\
\text { transcriptional regulator. } \\
\text { This is a nuclear protein and } \\
\text { functions as a transcriptional } \\
\text { regulator. }\end{array}$ & $U N$ & $U N$ & $U N$ & $U N$ & $\begin{array}{l}\text { (SS) MC3T3, Ogata et al. (1997 and 2008) } \\
\text { (SS) MG63, Lee et al. (2008) } \\
\text { (SS) MC3T3, Tanaka et al. (2005) }\end{array}$ \\
\hline IGF1 & $\begin{array}{l}\text { Insulin-like growth factor } \\
\text { Growth factor activity }\end{array}$ & $U N$ & $U N$ & $U N$ & $U N$ & \begin{tabular}{|l|} 
(SS) Mice Osteoblast, Lau et al. (2006) \\
(SS) UMR-106 cell, Sharp et al. (2009)
\end{tabular} \\
\hline IGFBP1 & $\begin{array}{l}\text { Insulin-like growth factor } \\
\text { binding protein } 1 \\
\text { Signal transduction, tissue } \\
\text { regeneration, cell protein } \\
\text { metabolic response } \\
\end{array}$ & $U N$ & $U N$ & $U N$ & $U N$ & (SS) Mice osteoblast, Lau et al. (2006) \\
\hline ITGB1 & $\begin{array}{l}\text { Integrin beta } 1 \\
\text { Receptors involved in cell } \\
\text { adhesion }\end{array}$ & $U N$ & $U N$ & \begin{tabular}{|c|} 
(pressure/ \\
distorsion ) \\
Haudenschild \\
et al. $(2009)$ \\
\end{tabular} & $U N$ & \\
\hline FGF2 & $\begin{array}{l}\text { Somatomedin C } \\
\text { Participant in biological } \\
\text { processes including } \\
\text { angiogenesis, embryonic } \\
\text { development and wound } \\
\text { healing. } \\
\end{array}$ & $U N$ & $U N$ & $U N$ & $U N$ & (stretching) Rat MSC, Qi et al. (2009) \\
\hline VEGFA & $\begin{array}{l}\text { Vascular endothelial growth } \\
\text { factor } A \\
\text { Chemoattractant, growth } \\
\text { factor, extracellular matrix } \\
\text { binding, protein binding } \\
\end{array}$ & $U N$ & $U N$ & $U N$ & $U N$ & $\begin{array}{l}\text { (SS) MC3T3, Thi et al. (2007) } \\
\text { (SS) Rat MSCs, Sharp et al. (2009) }\end{array}$ \\
\hline \multicolumn{7}{|c|}{ Osteogenic / Hypoxia-related genes } \\
\hline ALP & $\begin{array}{l}\text { Alkaline phosphatase } \\
\text { Alkaline phosphatase activity. } \\
\text { Involved in the development } \\
\text { of the skeletal system }\end{array}$ & $\begin{array}{l}\text { Grellier } \\
\text { et al. } \\
(2009) \\
\text { Liu et al. } \\
\text { (2011) } \\
\end{array}$ & & & $U N$ & (SS) Goat MSC, Knippenberg et al. (2005) \\
\hline RUNX2 & $\begin{array}{l}\text { Runt-related transcription } \\
\text { factor } 2 \\
\text { Participant in Osteoblastic } \\
\text { differentiation }\end{array}$ & $\begin{array}{c}\text { Grellier } \\
\text { et al. } \\
(2009) ; \\
\text { Liu et al. } \\
\text { (2011); } \\
\text { Hoey } \\
\text { et al. } \\
(2012) \\
\end{array}$ & & & $U N$ & (SS) Goat Adipose MSC, Knippenberg et al. (2005) \\
\hline HIF1A & $\begin{array}{l}\text { Hypoxia inducible factor } 1, \\
\text { alpha } \\
\text { Expressed by cells under } \\
\text { hypoxia }\end{array}$ & $U N$ & $U N$ & $U N$ & $U N$ & $\begin{array}{l}\text { (stretching) Rat skeletal muscle, Milkiewicz et al. } \\
(2007)\end{array}$ \\
\hline
\end{tabular}

Abbreviations: ALP = alkaline phosphatase; EGR1 = early growth response 1; FGF2 = fibroblast growth factor 2; HIF1A = hypoxia inducible factor 1 alpha; IER3 = immediate early response 3; IGF1 = insulin-like growth factor; IGFBP1 = insulin-like growth factor binding protein 1; ITGB1 = integrin beta 1; PTGES = prostaglandin E synthase; PTGS2 = prostaglandin-endoperoxide synthase 2; RUNX2 = runt-related transcription factor 2; VEGFA = vascular endothelial growth factor $\mathrm{A} ; U N=$ Unknown. 
(A)

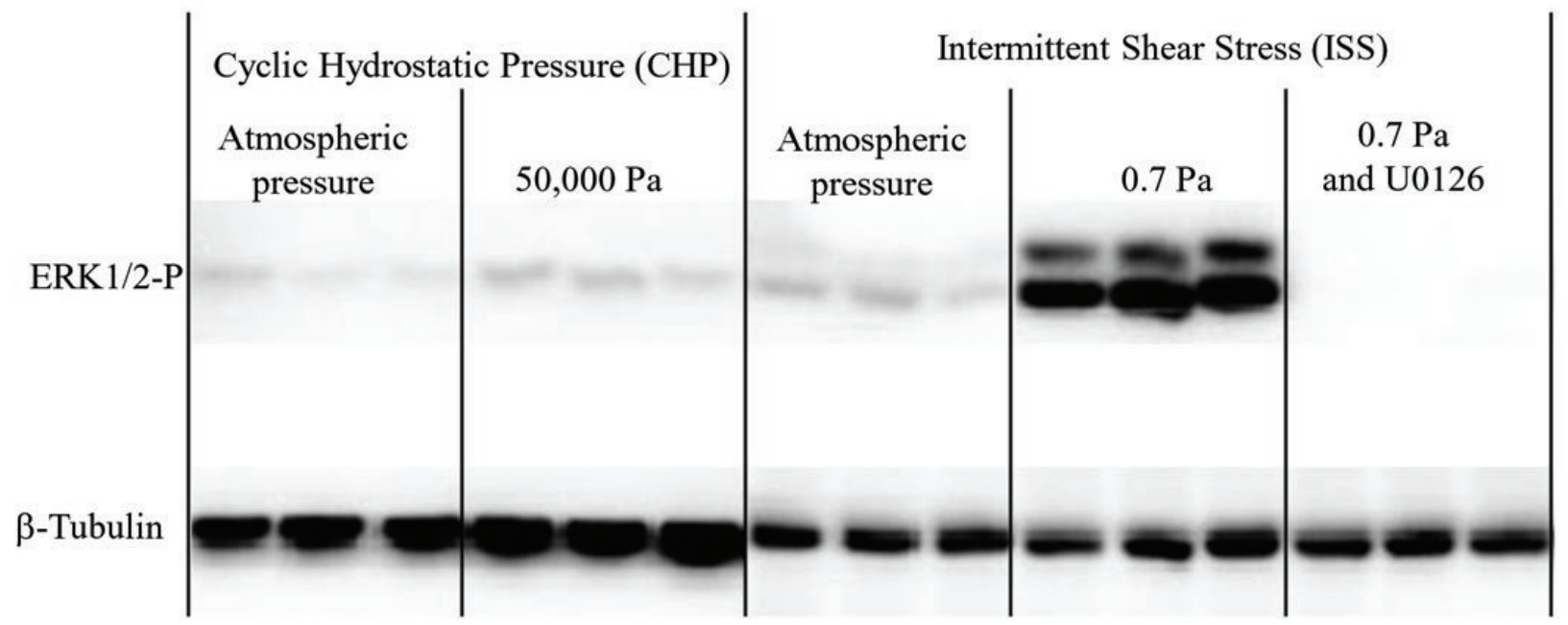

(B)

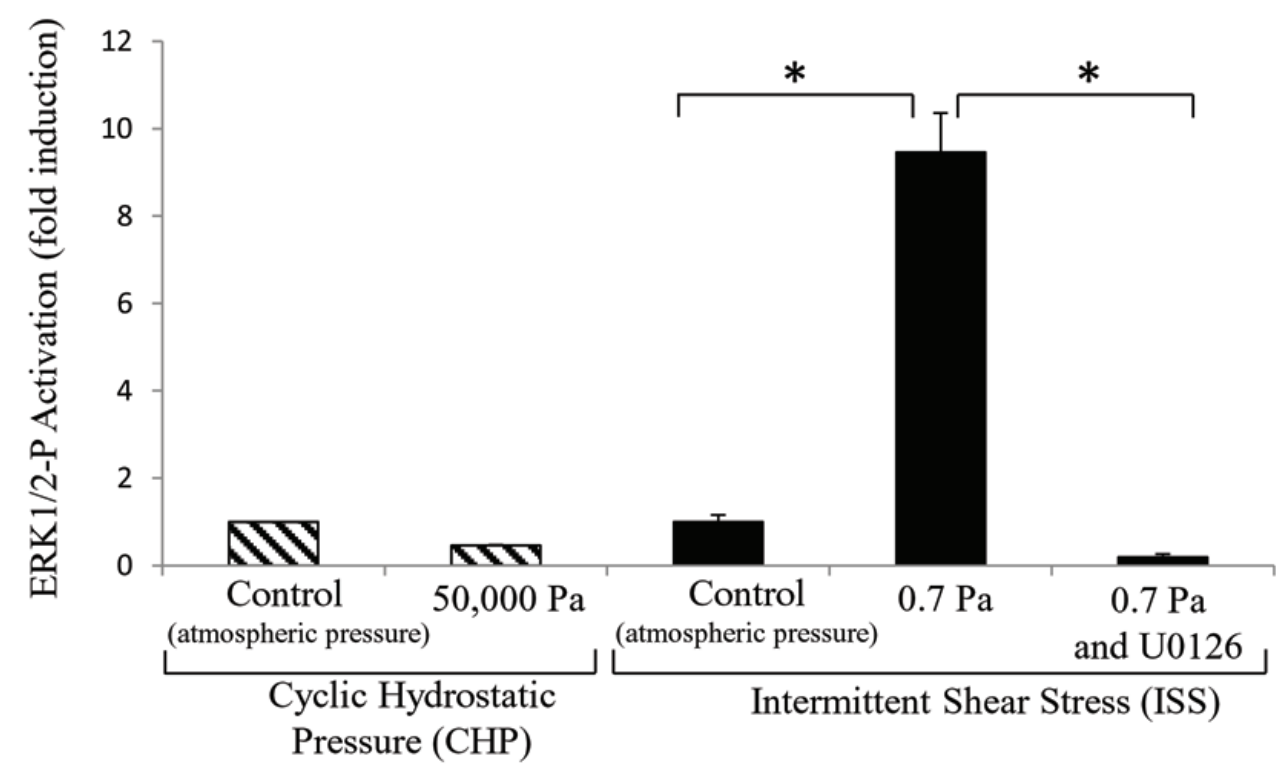

Fig. 5. Activation of ERK $1 / 2$ in response to exposure of hMSCs to either ISS ( $0.7 \mathrm{~Pa}$ at $2.8 \mathrm{~Hz}$ for $30 \mathrm{~min}$ ) or to CHP $(50,000 \mathrm{~Pa}$ at $2 \mathrm{~Hz}$ for $30 \mathrm{~min}$ ). (A) Expression of phospho-ERK1/2 (ERK1/2-P) was detected by Western blotting using anti-p-ERK1/2 for five of the experimental conditions tested. b-Tubulin was used as an internal control. (B) Band densities for phosphorylated ERK1/2. The fold up-regulation of the phosphorylated ERK1/2 bands was normalised using the b-tubulin results. A $t$-test between the CHP control and the CHP 50,000 Pa showed no significant difference. ERK $1 / 2$ activation was significantly increased after exposure of the hMSCs to ISS ( ${ }^{*} p<0.05$, compared by one-way ANOVA with Bonferroni's post-hoc test).

release of $\mathrm{NO}$ in the supernatant media was significantly $(p<0.05)$ higher only when the hMSCs were exposed to cyclic hydrostatic pressure at 50,000 $\mathrm{Pa}$ for $30 \mathrm{~min}$.

\section{Effects of the mechanical stimuli on hMSC gene expression \\ Expression of early mechano-sensitive genes}

In the present study, the following nine, early, mechanosensitive genes were selected and investigated (Table 1): prostaglandin-endoperoxide synthase 2 (PTGS2); prostaglandin E synthase (PTGES); immediate early response 3 (IER3); early growth response 1 (EGR1)); integrin beta 1 (ITGB1); fibroblast growth factor 2 (FGF2); insulin-like growth factor 1 (IGF1); insulin-like growth factor binding protein 1 (IGFBP1); and vascular endothelial growth factor A (VEGFA). The effects of the two mechanical stimuli tested were determined using total mRNA samples which were collected either immediately, $1 \mathrm{~h}$, or $6 \mathrm{~h}$ after exposure of hMSCs to each mechanical stimulus tested and were analysed using real time RT-PCR.

Compared to results obtained from respective controls (i.e., cells not exposed to the mechanical stimuli tested), the mean fold-upregulation of the genes monitored immediately after exposure of hMSCs to intermittent 

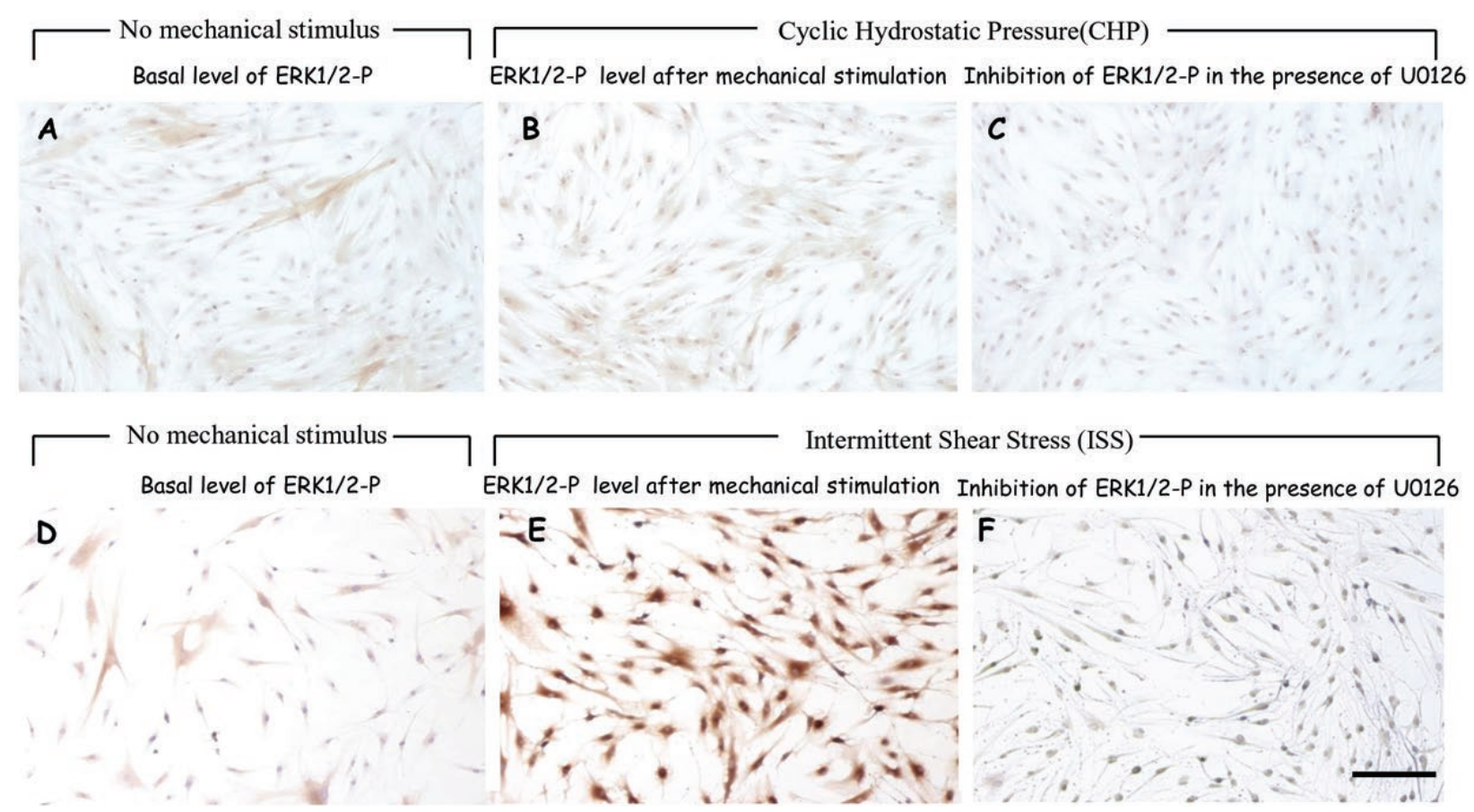

Fig. 6. Qualitative evidence of increased ERK1/2 phosphorylation level in hMSCs exposed to ISS. Representative light micrographs of hMSCs immunostained for phosphorylated ERK1/2. (A) hMSCs not exposed to CHP; (B) hMSCs after exposure to CHP (50,000 Pa at $2 \mathrm{~Hz}$ for $30 \mathrm{~min})$; (C) hMSCs after exposure to CHP (50,000 Pa at $2 \mathrm{~Hz}$ for $30 \mathrm{~min}$ ) in the presence of U0126 (10 mM/mL); (D) hMSC not exposed to ISS; (E) hMSCs after exposure to ISS $(0.7 \mathrm{~Pa}$ at $2.8 \mathrm{~Hz}$ for $30 \mathrm{~min})$; (F) hMSCs after exposure to ISS $(0.7 \mathrm{~Pa}$ at $2.8 \mathrm{~Hz}$ for $30 \mathrm{~min})$ in the presence of U0126 $(10 \mathrm{mM} / \mathrm{mL})$. Bar $=200 \mathrm{~mm}$.

shear stress of $0.7 \mathrm{~Pa}$ and $2.8 \mathrm{~Hz}$ for $30 \mathrm{~min}$, was 36.02 for PTGS2, 8.33 for IER3, 14.73 for EGR1, 10.23 for IGF1 and 28.14 for IGBP1 (Fig. 4A, black bars). Gene fold-upregulation was maximum $1 \mathrm{~h}$ after exposure to intermittent shear stress of $0.7 \mathrm{~Pa}$ and $2.8 \mathrm{~Hz}$ for $30 \mathrm{~min}$; the respective fold-values were 56.90 for PTGS2, 17.87 for IER3, 17.31 for IGF1, 38.93 for IGFBP1, 8.02 for ITGB1, 16.74 for FGF2 and 14.31-fold for VEGFA (Fig. 4B, black bars). Six hours after exposure to intermittent shear stress of $0.7 \mathrm{~Pa}$ and $2.8 \mathrm{~Hz}$ for $30 \mathrm{~min}$, gene fold-upregulation decreased but remained significantly $(p<0.5)$ elevated, for PTGS2 (22.25-fold), IER3 (7.4-fold), IGF1 (5.2-fold) and IGBP1 (26.9-fold) (Fig. 4C, black bars). Expression of the PTGES gene did not change after exposure to the mechanical stimuli.

Expression of the PTGS2, PTGES, IER3, EGR1, IGF1, IGBP1 ITGB1 and FGF2 genes either immediately ( $0 \mathrm{~h}$; Fig. 4A, black-hatched bars), $1 \mathrm{~h}$ (Fig. 4B, black-hatched bars) or $6 \mathrm{~h}$ (Fig. 4C, black-hatched bars) after exposure of hMSCs to cyclic hydrostatic pressure of 50,000 $\mathrm{Pa}$ and $2 \mathrm{~Hz}$ for $30 \mathrm{~min}$ was similar to the respective controls.

\section{Expression of the RUNX2, ALP and HIF1A genes}

The effect of the mechanical stimuli tested on the osteogenic differentiation of hMSCs was determined by examining the mRNA expression of RUNX2 and ALP (Table 1). Expression of both the ALP and RUNX2 genes was similar to the respective controls (i.e., cells not exposed to the mechanical stimuli tested) after exposure of hMSCs to either the intermittent shear stress or cyclic hydrostatic pressure tested in the present study (Figs. 4D, 4E and 4F).

Exposure of hMSCs to intermittent shear stress (at $0.7 \mathrm{~Pa}$ and $2.8 \mathrm{~Hz}$ for $30 \mathrm{~min}$ ) for $6 \mathrm{~h}$ resulted in 0.36 -fold downregulation of the HIF1A gene (Fig. 4F, black bar). In contrast, exposure of hMSCS to cyclic hydrostatic pressure (at 10,000 $\mathrm{Pa}$ and $2 \mathrm{~Hz}$ for $30 \mathrm{~min}$ ) for $6 \mathrm{~h}$ resulted in a 2.13-fold upregulation of the HIF1A gene (Fig. 4F, blackhatched bar).

\section{Effect of the mechanical stimuli on ERK1/2 activation in hMSCs}

The phosphorylation levels of ERK1/2 after exposure of hMSCs to Phorbol 12-Myristate 13-Acetate (PMA), but not to either one of the mechanical stimuli tested, served as controls in determining the effect of the mechanical stimuli of interest in the present study on ERK $1 / 2$ in these cells. The representative western blot results shown in Fig. 5A illustrate the phosphorylation levels of ERK1/2 under five different experimental conditions: (i) in hMSCs not exposed to cyclic hydrostatic pressure; (ii) in hMSCs exposed to cyclic hydrostatic pressure of 50,000 $\mathrm{Pa}$ and $2 \mathrm{~Hz}$ for $30 \mathrm{~min}$; (iii) in hMSCs not exposed to intermittent shear stress; (iv) in hMSCs exposed to intermittent shear stress of $0.7 \mathrm{~Pa}$ and $2.8 \mathrm{~Hz}$ for $30 \mathrm{~min}$; and (v) in hMSCs pretreated with U0126 (a specific inhibitor of ERK1/2) before exposure to intermittent shear stress of $0.7 \mathrm{~Pa}$ and $2.8 \mathrm{~Hz}$ for $30 \mathrm{~min}$. The results of the phosphorylated ERK1/2 band were normalised with respect to the beta-tubulin band (Figs. 5A and 5B). Significant $(p<0.5)$ changes were observed only when the hMSCs were exposed to 
intermittent shear stress of $0.7 \mathrm{~Pa}$ and $2.8 \mathrm{~Hz}$ for $30 \mathrm{~min}$ (Fig. 5B). Treatment of the hMSCs with U0126 prior to cell exposure to the aforementioned intermittent shear stress condition prevented phosphorylation of ERK1/2 (Fig. 5A). In contrast, the level of phosphorylated ERK1/2 did not change when the hMSCs were exposed to cyclic hydrostatic pressure of $50,000 \mathrm{~Pa}$ and $2 \mathrm{~Hz}$ for $30 \mathrm{~min}$ (Fig. 5A). These results are confirmed by the representative light micrographs in Fig. 6 (frames A through F), which illustrate ERK1/2 expression and inhibition under the conditions tested.

\section{Discussion}

The present study investigated, and compared, the early (in the order of minutes) responses of human MSCs to intermittent shear stress (ISS) and cyclic hydrostatic pressure (CHP) in order to determine which of these mechanical modalities is the most effective mechanical stimulus for hMSC differentiation and functions pertinent to new tissue formation. For this purpose, a panel of biomarkers associated with the responses of these cells to mechanical loading (Table 1) was assessed in order to establish differences and similarities in the responses of hMSCs to ISS and CHP.

Specifically, production of NO, a signalling molecule which leads to cellular-level responses that govern bone adaptation through remodelling (Knothe et al., 1998), was induced in a rate-dependent manner within $30 \mathrm{~min}$ of exposure to either type of the mechanical stimulus tested. These results corroborated literature reports which had used hMSCs from various anatomical locations, specifically, from human dental pulp (Kraft et al., 2010), human adipose tissue (Tjabringa et al., 2006; Bassaneze et al., 2010), as well as MSCs derived from goat adipose tissue (Knippenberg et al., 2005), mouse osteoblasts (Mullender et al., 2006), and mouse osteocytes (Santos et al., 2009), and observed NO release in response to intermittent and to steady shear stress of either 0.6 or $1 \mathrm{~Pa}$ and an oscillation frequency of $5 \mathrm{~Hz}$. To the best knowledge of the authors, the present study is the first to provide evidence that MSCs from human bone marrow release NO in response to a well-defined CHP stimulus (Fig. 3). $\mathrm{NO}$ is an important mediator of the response of bone cells to shear stress (Milkiewicz et al., 2007; Knothe et al., 1998); in addition, there is a correlation between the NO production rate and the level of the mechanical stimulus (Tjabringa et al., 2006; Santos et al.,2009).

It should be noted that the NO result in the present study was obtained when hMSCs cultured on rigid substrates were exposed to only a single mechanical stress, specifically, cyclic hydrostatic pressure. In contrast, when hMSCs loaded into 3D scaffolds were cultured in bioreactors they were exposed to a combination of mechanical stresses including shear stress, hydrostatic pressure and, sometimes, stretching. Under the conditions of the present study, the level of NO production was maximal when the hMSCs were exposed to either $0.7 \mathrm{~Pa}$ ISS or 50,000 Pa CHP (Fig. 3). These stress levels were considered optimal and were used subsequently for the rest of the experiments conducted in order to assess, and compare, similarities and differences in the responses of hMSCs to ISS and CHP. Most importantly, the results that NO production was significantly $(p<0.05)$ higher after exposure of hMSCs to ISS than to CHP (specifically, 14versus 2.6-fold, respectively) suggest that, by comparison, ISS rather than low magnitude CHP is more effective in triggering NO release from hMSCs (Fig. 3).

Expression of mRNA of a select panel of mechanosensitive genes (Table 1) was assessed at the optimal levels of the respective mechanical stimuli (i.e., 0.7 Pa for intermittent shear stress and 50,000 $\mathrm{Pa}$ for the cyclic hydrostatic pressure) established in the present study. Noteworthy aspects of these results are the great number of the affected genes, the notable differences in the genes expressed when hMSCs were exposed to the two mechanical stimuli tested and, most importantly, the scope of bioactivity of the respective compounds (Table 2).

Most importantly, the present study provided the first evidence that (i) PTGS2, IER3, EGR1, IGF1, IGFBP1, ITGB1, VEGFA and FGF2 genes are expressed in the

Table 2. Biological/physiological functions of some genes monitored in the present study.

\begin{tabular}{|c|c|c|c|}
\hline \multicolumn{2}{|l|}{ Gene } & Function & References \\
\hline early growth response 1 & EGR1 & $\begin{array}{l}\text { - } \quad \text { is a mechano-sensitive transcriptional factor } \\
\text { - } \quad \text { stimulates IGF-1R } \\
\text { - } \quad \text { plays an important role in bone formation in vivo } \\
\text { - participates in the bone healing process }\end{array}$ & $\begin{array}{l}\text { - } \quad \text { Press et al. }(2014) \\
\text { - Reumann et al. }(2011) \\
\end{array}$ \\
\hline fibroblast growth factor 2 & FGF2 & - is involved in vascular development, angiogenesis and bone healing & - $\quad$ Street et al. (2002) \\
\hline $\begin{array}{l}\text { insulin-like growth factor } \\
1 \text { (IGF1) }\end{array}$ & IGF1 & $\begin{array}{l}\text { - induces growth and hypertrophy in mechanically-stimulated and } \\
\text { damaged muscle both in vivo and in vitro } \\
\text { - } \quad \text { has a role in the accumulation and preservation of bone mass }\end{array}$ & $\begin{array}{l}\text { - Kawai et al. }(2013 \\
\text { - Bikle et al. }(2011) .\end{array}$ \\
\hline $\begin{array}{l}\text { insulin-like growth factor } \\
\text { binding protein } 1\end{array}$ & IGFBP1 & $\begin{array}{l}\text { - } \quad \text { binds insulin-like growth factors } \\
\text { - } \quad \text { is related the ERK } 1 / 2 \text { pathways } \\
\text { promotes cell migration }\end{array}$ & - Hannemann et al. (2013) \\
\hline integrin beta 1 (ITGB1) & ITGB1 & $\begin{array}{l}\text { - is a cell-membrane receptor and a member of the integrin family } \\
\text { - is involved in cell adhesion, mechanosense, and tissue repair }\end{array}$ & - Carbonell et al. (2013) \\
\hline $\begin{array}{l}\text { prostaglandin- } \\
\text { endoperoxide synthase } 2\end{array}$ & PTGS2 & $\begin{array}{l}\text { - } \quad \text { catalyses the synthesis of prostaglandin E2 } \\
\text { - } \quad \text { is involved in bone fracture repair } \\
\text { - } \quad \text { is regulated by ISS }\end{array}$ & - Tjabringa et al. (2006) \\
\hline $\begin{array}{l}\text { vascular endothelial } \\
\text { growth factor A }\end{array}$ & VEGFA & - is involved in vascular development, angiogenesis and bone healing & - $\quad$ Street et al. (2002) \\
\hline
\end{tabular}


response of human MSCs exposed to ISS, and that (ii) the FGF2 gene (but neither PTGES, EGR1 or VEGFA genes) are involved in the response of hMSCs to CHP. Last, but not least, the observed expression of mechano-sensitive genes (specifically, PTGS2, IER3, EGR1, IGF1, IGFBP1, ITGB1, FGF2 and VEGFA) returned to basal levels within 6 to $24 \mathrm{~h}$ after exposure of the hMSCs to the two mechanical stimuli tested (data not shown). This result from the present study is pertinent, and applicable, to the operation of bioreactors which are used for tissue engineering purposes: in order to promote the aforementioned gene level responses in the bioreactor milieu, repeated exposures of the cells to the mechanical stimulus may be required every 6 to $24 \mathrm{~h}$.

The effects of mechanical stimuli in the differentiation of hMSCs along specific phenotype pathways have been of great interest both in the cell biology and tissue engineering fields. Expression of RUNX2 (a gene towards the end of the middle part of the time course of differentiation along the osteogenic pathway) (Hughes et al., 2006) from hMSCS exposed to both mechanical stimuli tested in the present study was similar to that obtained from the respective controls (Fig. 4); these results are in agreement with literature reports of no changes in RUNX2 gene expression after exposure of hMSCs to shear stress of 1.2 Pa for $30 \mathrm{~min}$ (Grellier et al., 2009). Upregulation of other genes associated with the osteogenic pathway (i.e., RUNX2, Osterix, ALP) when osteocompetent cells (i.e., MC3T3, MSCs) were exposed to ISS was also reported in the literature (Scaglione et al., 2008; Kraft et al., 2010; Milkiewicz et al., 2007). The disagreement between the literature reports and the aforementioned results of the present study may be due to differences of the experimental conditions used including different osteogenic media (Scaglione et al., 2008; Sharp et al., 2009; Kraft et al., 2010), type of substrate material (for example, poly(D,Llactic-coglycolic acid), structure (i.e., 3-D) of the substrate scaffolds (Liu et al., 2011; Holtorf et al., 2005; Liu et al., 2012; Ban et al., 2011)), type of the mechanical stimulus (for example, sustained shear stress (Grellier et al., 2009)), and species (for example, rat MSCs; Holtorf et al., 2005). The results of the present study focused exclusively on the investigation of the early (specifically, immediately after exposure $(0 \mathrm{~h})$, as well as at $1 \mathrm{~h}$ and $6 \mathrm{~h}$ ) responses of hMSCs following a $30 \mathrm{~min}$ exposure to mechanical loading, and provided an important addition to current knowledge that longer (e.g., in terms of duration and frequency) exposures of osteocompetent cells (i.e., MSCs) promote osteogenic differentiation. Last, but not least, the down-regulation of HIF1A (a regulator for angiogenesis under low oxygen tension conditions) observed $6 \mathrm{~h}$ after the hMSCs were exposed to ISS (but not to CHP; Fig. 4F) may be interpreted that the ISS (but not CHP) milieu provided conditions for efficient transport of oxygen.

In order to confirm aspects of pertinent mechanotransduction mechanisms, activation of ERK1/2 under ISS and CHP was examined because this pathway participates in cellular mechanotransduction, specifically, in the "translation" of mechanical signals into intracellular biological signals that regulate cell proliferation and differentiation (Fan et al., 2006; Liu et al., 2006; Kanno et al., 2007; Ward et al., 2007). This effect was corroborated by the result of the present study that ERK1/2 activation occurred only when hMSCs were exposed to ISS (Fig. 5 and Fig. 6). Confirmation of ERK1/2 mediation was provided by the fact that pre-treatment of hMSCs with U0126, a specific inhibitor of ERK1/2 activation, abolished the effect of ISS on early PTGS2 gene activation (data not shown). This result is similar to that observed with, and reported for, human dental pulp MSCs (Kraft et al., 2010). In contrast, ERK $1 / 2$ was not activated when the hMSCs tested in the present study were exposed to CHP (Fig. 5 and Fig. 6). In this regard, the results of the present investigation differ from literature reports that exposure of hMSCs to cyclic hydrostatic pressure (Kim et al., 2007) and to cyclic compression (Pelaez et al., 2012) induces early activation of the ERK1/2 pathway. The aforementioned differences regarding activation of ERK $1 / 2$ by CHP may be reconciled by taking into consideration that, when hMSCs were seeded into either fibrin (Pelaez et al., 2012) or poly lactic-coglycolic acid (Simmons et al., 2003) scaffolds and submitted to compression, the cells were simultaneously exposed not only to compression or CHP (as in the case of the present experimental set-up) but also to stretching of the underlying polymeric substrate (Simmons et al., 2003). Scaffolds composed of flexible materials may stretch upon compression and/or exposure to ISS; in addition, compression of such scaffolds under CHP induces shear stress through fluid flow inside porous scaffold-structures.

The 3D and 2D culture modalities are "models" which provide opportunities to investigate in vitro cell responses and functions pertinent to many biomedical applications. Each of the aforementioned models requires experimental methodologies which vary in their complexity as well as in the necessary expertise and required instrumentation. For example, 2D models allow easier visualisation of patterns of cell adhesion and morphology using routine microscopy techniques and instruments such as light and/ or fluorescence microscopes. In contrast, analyses of the aforementioned cell functions in 3D models require special instruments (such as confocal microscopes) and pertinent, specialised expertise. Due to the special architecture and structure of the $3 \mathrm{D}$ systems, the mechanical milieu is more complex (but also more pertinent) to studies with cells which focus on the combined (and simultaneous) effect(s) of several types of mechanical stimuli. Undoubtedly, the major advantage of the 3D systems is that they resemble "more closely" the in vivo scenario. It should be kept in mind, however, that all these systems are "models" with certain advantages and limitations; these aspects should be taken into consideration (and not be forgotten) by the researchers who use these models/systems. It could be argued, however, that at the cellular level (which is appropriate for a molecular-level study), the 2D culture scenario is another pertinent model.

In summary, the fact that exposure of hMSCs to ISS induced up-regulation of all molecular/gene markers tested in the present study, provided evidence of the importance of the effects of this mechanical stimulus on hMSCs because the upregulated compounds are bioactive and are involved in regulating or/and in controlling various aspects of the tissue healing process. In contrast, the evidence that exposure of hMSCs to CHP resulted in small up-regulation 
of fewer of the genes tested, but no up-regulation of the ERK1/2 pathway, suggests that the regime of CHP tested does not affect these functions of hMSCs. These results establish that, compared to CHP, ISS is a more effective stimulus for inducing hMSC responses pertinent to the bone healing process. Such findings have important relevance for biomedical applications and could be used in designing bioreactors to provide appropriate micro-environments for exposing stem cells to mechanical (specifically, ISS rather than CHP) stimuli as well as to pertinent biochemical cues in order to achieve either stem cell expansion or their differentiation along specific phenotype pathways.

\section{Acknowledgements}

This project was supported by the French National Agency Centre National de Recherche Scientifique (CNRS). The authors acknowledge financial support from CNRS and from ANR OMBIOS (ANR-11-BS09-0036), ANR VIASTEM (ANR-12-BSV5-0015) and ANR GLASSBONE (ANR-08-TECS-004). The authors also wish to thank the IVTV (ANR-10-EQPX-06-01) for assistance with calculations of the mechanical loads during cyclic hydrostatic pressure. We confirm that the authors have no conflicts of interest to declare and there has been no significant financial support for this work that could influence its outcome.

\section{References}

Ban Y, Wu Y, Yu T, Geng N, Wang Y, Liu X, Gong P (2011). Response of osteoblasts to low fluid shear stress is time dependent. Tissue Cell 43: 311-317.

Bassaneze V, Barauna VG, Lavini-Ramos C, Kalil J, Schettert IT, Miyakawa AA, Krieger JE (2010). Shear stress induces nitric oxide-mediated vascular endothelial growth factor production in human adipose tissue mesenchymal stem cells. Stem Cells Dev 19: 371-378.

Bensidhoum M, Chapel A, Francois S, Demarquay C, Mazurier C, Fouillard L, Bouchet S, Bertho JM, Gourmelon P, Aigueperse J, Charbord P, Gorin NC, Thierry D, Lopez M (2004). Homing of in vitro expanded Stro-1or Stro-1+ human mesenchymal stem cells into the NOD/ SCID mouse and their role in supporting human CD34 cell engraftment. Blood 103: 3313-3319.

Bikle DD, Wang Y (2011). Insulin-like growth factor-I and bone. IBMS Bonekey 8: 328-341.

Carbonell WS, DeLay M, Jahangiri A, Park CC, Aghi M $\mathrm{K}$ (2013). B1 Integrin targeting potentiates antiangiogenic therapy and inhibits the growth of bevacizumab-resistant glioblastoma. Cancer Res 73: 3145-3154.

Fan X, Rahnert JA, Murphy TC, Nanes MS, Greenfield EM, Rubin J (2006). Response to mechanical strain in an immortalized pre-osteoblast cell is dependent on ERK 1/2. J Cell Physiol 207: 454-460.

Friedenstein AJ, Piatetzky-Shapiro II, Petrakova KV (1966). Osteogenesis in transplants of bone marrow cells. J Embryol Exp Morphol 16: 381-390.
Friedenstein AJ, Petrakova KV, Kurolesova AI, Frolova GP (1968). Heterotopic transplants of bone marrow. Transplantation 6: 230-247.

Gardel LS, Serra L, Reis RL, Gomes ME (2014). Use of perfusion bioreactors and large animal models for long bone tissue engineering. Tissue Eng Part B Rev 20: 126146.

Grellier M, Bareille R, Bourget C, Amedee J (2009). Responsiveness of human bone marrow stromal cells to shear stress. J Tissue Eng Regen Med 3: 302-309.

Hannemann A, Nauck M, SpielhageNiemann INC, Völzke H, Wallaschofski H, Friedrich N (2013). The association between insulin-like growth factor I and bone turnover markers in the general adult population. Bone 56: 184-190.

Haudenschild AK, Hsieh AH, Kapila S, Lotz JC (2009). Pressure and distortion regulate human mesenchymal stem cell gene expression. Ann Biomed Eng 37: 492-502.

Hoey DA, Tormey S, Ramcharan S, O'Brien FJ, Jacobs CR (2012). Primary cilia-mediated mechanotransduction in human mesenchymal stem cells. Stem Cells 30: 25612570 .

Holtorf HL, Jansen JA, Mikos AG (2005). Flow perfusion culture induces the osteoblastic differentiation of marrow stroma cell-scaffold constructs in the absence of dexamethasone. J Biomed Mater Res A 72: 326-334.

Huang C, Ogawa R (2012) Effect of hydrostatic pressure on bone regeneration using human mesenchymal stem cells. Tissue Eng Part A 18: 2106-2113.

Hughes FJ, Turner W, Belibasakis G, Martuscelli G (2006). Effects of growth factors and cytokines on osteoblast differentiation. Periodontology 41: 48-72.

Kanno T, Takahashi T, Tsujisawa T, Ariyoshi W, Nishihara T (2007). Mechanical stress-mediated Runx2 activation is dependent on Ras/ERK1/2 MAPK signaling in osteoblasts. J Cell Biochem 101: 1266-1277.

Kim SH, Choi YR, Park MS, Shin JW, Park KD, Kim SJ, Lee JW (2007). ERK $1 / 2$ activation in enhanced osteogenesis of human mesenchymal stem cells in poly (lactic-glycolic acid) by cyclic hydrostatic pressure. J Biomed Mater Res A 80: 826-836.

Knippenberg M, Helder MN, Doulabi BZ, Semeins CM, Wuisman P, Klein-Nulend J (2005). Adipose tissuederived mesenchymal stem cells acquire bone celllike responsiveness to fluid shear stress on osteogenic stimulation. Tissue Eng 11: 1780-1789.

Knothe Tate ML, Niederer P, Knothe U (1998). In vivo tracer transport through the lacunocanalicular system of rat bone in an environment devoid of mechanical loading. Bone 22: 107-117.

Kraft DCE, Bindslev DA, Melsen B, Abdallah BM, Kassem M, Klein-Nulend J (2010). Mechanosensitivity of dental pulp stem cells is related to their osteogenic maturity. Eur J Oral Sci 118: 29-38.

Kreke MR, Sharp LA, Lee YW, Goldstein AS (2008). Effect of intermittent shear stress on mechanotransductive signaling and osteoblastic differentiation of bone marrow stromal cells. Tissue Eng Part A 14: 529-537.

Lau KHW, Kapur S, Kesavan C, Baylink DJ (2006). Up-regulation of the Wnt, estrogen receptor, insulinlike growth factor-I, and bone morphogenetic protein 
pathways in $\mathrm{C} 57 \mathrm{BL} / 6 \mathrm{~J}$ osteoblasts as opposed to $\mathrm{C} 3 \mathrm{H} / \mathrm{HeJ}$ osteoblasts in part contributes to the differential anabolic response to fluid shear. J Biol Chem 281: 9576-9588.

Lee DY, Yeh CR, Chang SF, Lee PL, Chien S, Cheng CK, Chiu JJ (2008). Integrin-mediated expression of bone formation-related genes in osteoblast-like cells in response to fluid shear stress: roles of extracellular matrix, Shc, and mitogen-activated protein kinase. J Bone Miner Res 23: 1140-1149.

Liu J, Liu T, Zheng Y, Zhao Z, Liu Y, Cheng H, Luo S, Chen Y (2006). Early responses of osteoblast-like cells to different mechanical signals through various signaling pathways. Biochem Biophys Res Commun 348: $1167-$ 1173.

Liu L, Shao L, Li B, Zong C, Li J, Zheng Q, Tong X, Gao C, Wang J (2011). Extracellular signal-regulated kinase $1 / 2$ activated by fluid shear stress promotes osteogenic differentiation of human bone marrow-derived mesenchymal stem cells through novel signaling pathways. Int J Biochem Cell Biol 43: 1591-1601.

Liu L, Yu B, Chen J, Tang Z, Zong C, Shen D, Zheng Q, Tong X, Gao C, Wang J (2012). Different effects of intermittent and continuous fluid shear stresses on osteogenic differentiation of human mesenchymal stem cells. Biomech Model Mechanobiol 11: 391-401.

Kawai M, Rosen CJ (2012). The insulin-like growth factor system in bone: basic and clinical implications. Endocrinol Metab Clin North Am 41: 323-333.

Milkiewicz M, Doyle JL, Fudalewski T, Ispanovic E, Aghasi M, Haas TL (2007). HIF-1alpha and HIF-2alpha play a central role in stretch-induced but not shear-stressinduced angiogenesis in rat skeletal muscle. J Physiol 583: 753-766.

Mullender MG, Dijcks SJ, Bacabac RG, Semeins CM, Van Loon JJWA, Klein-Nulend J (2006). Release of nitric oxide, but not prostaglandin E2, by bone cells depends on fluid flow frequency. J Orthop Res 24: 1170-1177.

Miyanishi K, Trindade MC, Lindsey DP, Beaupré GS, Carter DR, Goodman SB, Schurman DJ, Smith RL (2006). Effects of hydrostatic pressure and transforming growth factor-beta 3 on adult human mesenchymal stem cell chondrogenesis in vitro. Tissue Eng 12: 1419-1428.

Nagatomi J, Arulanandam BP, Metzger DW, Meunier A, Bizios R (2001). Frequency- and duration-dependent effects of cyclic pressure on select bone cell functions. Tissue Eng 7: 717-728.

Ogata T (1997). Fluid flow induces enhancement of the Egr-1 mRNA level in osteoblast-like cells: involvement of tyrosine kinase and serum. J Cell Physiol 170: 27-34.

Ogata T (2008). Egr-1 mRNA induction by medium flow involves mRNA stabilization and is enhanced by the p38 inhibitor SB203580 in osteoblast-like cells. Acta Physiol 194: 177-188.

Pelaez D, Arita N, Cheung HS (2012). Extracellular signal-regulated kinase (ERK) dictates osteogenic and/or chondrogenic lineage commitment of mesenchymal stem cells under dynamic compression. Biochem Biophys Res Commun 417: 1286-1291.

Press T, Viale-Bouroncle S, Felthaus O, Gosau M, Morsczeck C (2015). EGR1 supports the osteogenic differentiation of dental stem cells. Int Endod J: 48: 185192.

Qi M, Zou S, Han L, Zhou H, Hu J (2009). Expression of bone-related genes in bone marrow MSCs after cyclic mechanical strain: implications for distraction osteogenesis. Int J Oral Sci 1: 143-150.

Reumann MK, Strachna O, Lukashova L, Verdelis K, Donnelly E, Boskey AL, Mayer-Kuckuk P (2011a). Early growth response gene 1 regulates bone properties in mice. Calcif Tissue Int 89: 1-9.

Reumann MK, Strachna O, Yagerman S, Torrecilla D, Kim J, Doty SB, Lukashova L, Boskey AL, MayerKuckuk P (2011b). Loss of transcription factor early growth response gene 1 results in impaired endochondral bone repair. Bone 49: 743-752.

Santos A, Bakker AD, Zandieh-Doulabi B, Semeins CM, Klein-Nulend J (2009). Pulsating fluid flow modulates gene expression of proteins involved in Wnt signaling pathways in osteocytes. J Orthop Res 27: 1280-1287.

Scaglione S, Wendt D, Miggino S, Papadimitropoulos A, Fato M, Quarto R, Martin I (2008). Effects of fluid flow and calcium phosphate coating on human bone marrow stromal cells cultured in a defined 2D model system. J Biomed Mater Res A 86: 411-419

Sharp LA, Lee YW, Goldstein AS (2009). Effect of low-frequency pulsatile flow on expression of osteoblastic genes by bone marrow stromal cells. Ann Biomed Eng 37: 445-453.

Simmons CA, Matlis S, Thornton AJ, Chen S, Wang CY, Mooney DJ (2003). Cyclic strain enhances matrix mineralization by adult human mesenchymal stem cells via the extracellular signal-regulated kinase (ERK1/2) signaling pathway. J Biomech 36: 1087-1096.

Street J, Bao M, deGuzman L, Bunting S, Peale FV, Ferrara N, Steinmetz H, Hoeffel J, Cleland JL, Daugherty A, van Bruggen N, Redmond HP, Carano RAD, Filvaroff EH (2002). Vascular endothelial growth factor stimulates bone repair by promoting angiogenesis and bone turnover. Proc Natl Acad Sci USA 99: 9656-9661.

Sunters A, Armstrong VJ, Zaman G, Kypta RM, Kawano Y, Lanyon LE, Price JS (2010). Mechanotransduction in osteoblastic cells involves strain-regulated estrogen receptor alpha-mediated control of insulin-like growth factor (IGF) I receptor sensitivity to ambient IGF, leading to phosphatidylinositol 3-kinase/AKT-dependent Wnt/LRP5 recept. J Biol Chem 285: 8743-8758.

Tanaka SM, Sun HB, Roeder RK, Burr DB, Turner CH, Yokota H (2005). Osteoblast responses one hour after loadinduced fluid flow in a three-dimensional porous matrix. Calcif Tissue Int 76: 261-271.

Thi MM, Iacobas DA, Iacobas S, Spray DC (2007). Fluid shear stress upregulates vascular endothelial growth factor gene expression in osteoblasts. Ann NY Acad Sci 1117: $73-81$.

Tjabringa GS, Vezeridis PS, Zandieh-Doulabi B, Helder MN, Wuisman PIJM, Klein-Nulend J (2006). Polyamines modulate nitric oxide production and COX2 gene expression in response to mechanical loading in human adipose tissue-derived mesenchymal stem cells. Stem Cells 24: 2262-2269. 
Wang Y, Li Y, Fan X, Zhang Y, Wu J, Zhao Z (2011). Early proliferation alteration and differential gene expression in human periodontal ligament cells subjected to cyclic tensile stress. Arch Oral Biol 56: 177-186.

Ward DF, Salasznyk RM, Klees RF, Backiel J, Agius P, Bennett K, BoskeyA, Plopper GE (2007). Mechanical strain enhances extracellular matrix-induced gene focusing and promotes osteogenic differentiation of human mesenchymal stem cells through an extracellular-related kinase-dependent pathway. Stem Cells Dev 16: 467-480.

Yeatts AB, Choquette DT, Fisher JP (2013). Bioreactors to influence stem cell fate: augmentation of mesenchymal stem cell signaling pathways via dynamic culture systems. Biochem Biophys Acta 1830: 2470-2480.

\section{Discussion with Reviewers}

Reviewer II: The authors applied relatively low magnitudes of CHP to MSCs, but cells and tissues of the musculoskeletal system will be subjected to much higher magnitudes of CHP in vivo. Do the authors believe that their findings that ISS is a more effective stimulus to MSCs than CHP are universal, or restricted to the magnitudes investigated in this study?

Authors: We agree that in some musculoskeletal areas, such as articular cartilage, cells are exposed to mechanical loads in the MPa range. However, the magnitude of mechanical forces experienced by either organs, tissues or cells of the body is extremely different (from a few Pascals (shear stress) to Mega Pascals (hydrostatic pressure). What exactly is the portion/level of the mechanical forces applied on the bone cells and how these cells perceive and convert these signals give rise to many questions. The ranges of the mechanical stimuli used in the present study were defined based on pertinent literature reports, in which the same type of mechanical stimuli at the cellular level was used. These stimuli magnitudes were within the same order as the values (0.8-3 Pa) of shear stress in vivo (Weinbaum et al., 1994). The authors believe that ISS is a more effective stimulus to MSCs than CHP in 2D models investigated in this study. But it should be kept in mind, however, that 2D systems are "models" with certain advantages and limitations; these aspects should be taken into consideration (and not be forgotten) by the researchers who use these models/systems.

\section{Additional Reference}

Weinbaum S, Cowin SC, Zeng Y (1994). A model for the excitation of osteocytes by mechanical loading-induced bone fluid shear stresses. J Biomech 27: 339-360.

Editor's Note: Scientific Editor in charge of the paper: Martin Stoddart. 